Our Nature (2009) 7:139-145

\title{
Some Fresh Water Algae of Oil Refinery Effluent Drains of Assam, India
}

\author{
P.P. Baruah*, B. Kakati and I. Ahmed \\ Department of Botany, Gauhati University, Guwahati- 781014, Assam, India \\ *E-mail: partha_porosh@yahoo.co.in
}

Received: 20.03.2009, Accepted: 18.09.2009

\begin{abstract}
The present paper deals with the morpho-taxonomic account of some hitherto unknown fresh water algal species of hydrocarbon polluted refinery drains of Assam. Twenty two taxa of class Chlorophyceae, Bacillariophyceae, Euglenineae and Cyanophyceae were identified from three effluent drains of Guwahati Oil Refinery. Cyanophyceae with 11 species was the dominant algal group in the study sites and Oscillatoria was the dominant genus with 8 species.
\end{abstract}

Key words: Fresh water algae, Oscillatoria, oil refinery effluent, Assam

\section{Introduction}

The Guwahati oil refinery is located at Latitude $26^{\circ} 10^{\prime} \mathrm{N}$ and Longitude $92^{\circ} 49^{\prime} \mathrm{E}$ in the state of Assam (India) at an elevation of $55 \mathrm{~m}$ msl. The oil refinery was established in the year 1962 and is situated in the eastern part of the city itself. There are as many as three drains coming out from the refinery campus carrying sludge waste. The drains either flow towards the mighty Brahmaputra River or to Bharalu River, a perennial tributary of Brahmaputra. The drains are perennial in nature and hardly dry up. These drains often have very low water levels during winter season and that is too high during summer. The area has a subtropical monsoonal climate with $29^{\circ} \mathrm{C} / 19^{\circ} \mathrm{C}$ average maximum /minimum temperature and $1600 \mathrm{~mm}$ average annual rainfall. The hot and humid climate and slightly polluted habitats influence the growth of few algae in the drains of the area.
Information pertaining to diversity of algal flora of Assam (India) is meager (Parukutty, 1939; Bordoloi, 1974; Devi, 1981; Devi and Boissya, 1981; Talukder, 1997; Choudhury, 2004). Since there has been no report on algae from any refinery sites of Assam, an attempt has therefore been made to describe the algae reported to be present in the water drains flowing through the Guwahati oil refinery site.

\section{Materials and methods}

The study was conducted for a year from May, 2008 to April, 2009.Algal samples were collected in two months intervals. The samples were collected in plastic tubes from three different effluent drains flowing through the Guwahati oil refinery with the help of plankton mesh net (size $0.5 \mathrm{~mm}$ ) and by scrubbing the slippery pebbles. The collection timings were set between 9-12 am. 
All the samples were preserved in $4 \%$ formaldehyde solution on the spot. Geographical position, sample no., date of collection etc. of each locality was also noted on the field diary. They were brought to the laboratory of the Department of Botany, Gauhati University for further investigation. Chlorophycean algae were stained with iodine and mounted in glycerin. Bacillariophycean taxa were studied after clearing the frustules by concentrated sulphuric acid and potassium dichromate method of Patrick and Reimer (1966). Cyanophycean algae were stained with dilute safranin and mounted in glycerin. Identification was confirmed by cross checking each specimen with literature and monographs (Kützing, 1895; Gomont, 1892a, b; Hustedt, 1930; Fritsch, 1935, 1961; Smith 1950; Desikachary, 1959; Islam and Haroon, 1975; Prescott, 1975; Hirose et al., 1977; Islam and Chaudhary, 1979; Germain, 1981; Sarode and Kamat, 1984). All the samples have been deposited in the repository of Department of Botany, Gauhati University.

\section{Morpho-taxonomic descriptions}

Class: Chlorophyceae

Order: Volvocales

Family: Chlorellaceae

Genus: Chlorella Beijernick. 1890

1. Chlorella vulgaris Beij. (Fig. 7)

Fritsch 1961, P. 146, Fig. 37

Solitary spherical cell, cell membrane thin. Cup shaped parietal chloroplast, very prominent. Cell diameter varies from 7.8$9.3 \mu \mathrm{m}$.

Class: Bacillariophyceae

Order: Pinnales
Family: Fragillarioideae

Genus: Fragillaria Lyngybye. 1819; Emend. Rabenhorst. 1864

2. Fragillaria virescens Ralf. (Fig. 16)

Hustedt 1930, P. 142, Fig. 144

Frustules attached together to form chains, broadly linear, valves $64.2 \mu \mathrm{m}$ long and 8.7 $\mu \mathrm{m}$ broad, pseudoraphe, striae marginal, thin, central area unilateral, valves elliptic, striae $12-19$ in $10 \mu \mathrm{m}$.

3. Fragillaria crotonensis var. praelonga Grun. (Fig. 12)

Smith 1950, P. 479, Fig. 386

Frustules $127 \mu \mathrm{m}$ long and $9 \mu \mathrm{m}$ broad at the tip. Valves mostly straight, rod shaped or lenceolata, only a pseudo-raphe present.

Genus: Synedra Ehrenberg. 1830

4. Synedra ulna (Nitz) Her. (Fig. 11)

Hustedt 1930, P. 151, Fig. 159.

Valves $122 \mu \mathrm{m}$ long and $10 \mu \mathrm{m}$ broad, linear to lenceolate and tapering at the ends, ends rounded pseudoraphe narrow, linear, central area absent or present. Striae 9-11 in $10 \mu \mathrm{m}$. Coarse.

Genus : Pinnularia Ehrenberg. 1838

5. Pinnularia gibba Ehr. Var. mesogongyla (Ehr.) Hust. (Fig. 8)

Islam and Haroon 1975, P. 32, Pl. 3, Fig. 56. Frustules $50.49 \mu \mathrm{m}$ long and $13.2 \mu \mathrm{m}$ broad, have the general form of an oblong box, isobilateral with 2 planes of symmetry, both valve with a fully differentiated raphe.

Family: Naviculoideae

Genus: Nevicula Bory 
6. Nevicula rhynchocephala Kuetz. (Fig. 17)

Hustedt 1930, P. 296, Fig. 501.

Valves $50.24 \mu \mathrm{m}$ long and $12.2 \mu \mathrm{m}$ broad, oblong slender, with slightly dilated capitates ends, raphe thin and straight, axial area narrow, linear, central and rounded, somewhat rhombic, striae 14-16 in $10 \mu \mathrm{m}$. Denser towards the ends, radial in the middle and convergent at the ends.

7. Nevicula cryptocephala Kutz. (Fig. 13) Germain 1981, P. 188, Pl. 72, Fig. 2.

Frustules $29.7 \mu \mathrm{m}$ long and $5.95 \mu \mathrm{m}$ broad at the middle, raphe occupying the apical axis, both polar and central nodules are elongated at the apical direction and enclosed along the raphe, both valve with a fully differentiated raphe.

\section{Genus: Gomphonema Agardh 1824}

8. Gomphonema lenceolatum Her. (Fig. 9) Sarode and Kamat 1984, P. 190, Pl. 22, Fig. 514.

Valves $86 \mu \mathrm{m}$ long and $22 \mu \mathrm{m}$ broad, lanceolate, clevate with distinctly rounded apex and base, base somewhat narrow, linear central area slightly unilateral with an isolated stigma on the opposite sides, striae $11-12$ in $10 \mu \mathrm{m}$. Radial and lineate.

\section{Gomphonema parvulum (Kg.) Grun.} (Fig. 10)

Islam and Chaudhary 1979, Pl. 7, Fig. 63. Frustules $33 \mu \mathrm{m}$ long and $11.55 \mu \mathrm{m}$ broad at the middle, has only a single often deep incised chromatophore, the median portion of which lies against one of the girdle, while the rest spread over on to the valve faces and most of the other girdle. The central area is asymmetrical with a single long stria on one side terminating in a distinct stigma, and a single short stria on the other side. Striae are almost perpendicular to the raphe.

Class: Euglenineae

Family: Euglenaceae

Genus: Euglena Ehrenberg 1838

10. Euglena acus Her. (Fig. 15)

Fritsch 1935, P. 725, Fig. 239.

Planktonic, unicellular, uniflagillate, cell elongated and the posterior end more pointed. Cell has a gullet at the enterior end and one contractile vacuole. Eyespot present at the anterior end. Chloroplast numerous and discoid. Cells $2-4 \mu \mathrm{m}$ in breadth and 7-9 times longer than the breadth.

\section{Genus : Phacus Dujardin 1841}

11. Phacus acuminatus a. Stokes. (Fig. 14)

Cell body 23-40 $\mu \mathrm{m}$ long, 20-30 $\mu \mathrm{m}$ wide, dorsal view nearly spherical; cauda short Vshaped and slightly curved or straight, striae also straight; a locomotive flagellum nearly the same as the cell body in length; paramylon bodies disc-shaped with a hole at the center.

Class: Cyanophyceae

Order: Nostocales

Family: Oscillatoriaceae

Genus: Oscillatoria Voucher, 1803

12. Oscillatoria Formosa Bory (Fig 1)

Hirose 1977, P. 102, Pl. 44, Fig. 33; Prescott 1975, P. 489, Pl. 109, Figs. 10-11.

Trichomes straight and rather firm, curved and slightly tapering towards the apex. Apical cell conical, not capitates, without a calyptras. Trichomes constricted at the cross walls, which contains micro-granulars. Cells 
P.P. Baruah, B. Kakati and I. Ahmed / Our Nature (2009) 7: 139-145

4-6 $\mu \mathrm{m}$ in diameter, 2.5-6 $\mu \mathrm{m}$ long. Dark blue-green in colour.

13. Oscillatoria nigra Vaucher. (Fig. 2)

Hirose 1977, P. 110, Pl. 45, Fig. 12; Prescott 1975, P. 489, Pl. 109, Fig. 18.

Trichomes straight or slightly twisted, not tapering towards the apex, straight or curved. Apical cell rounded or capitates. Trichomes constricted at the cross walls, which contains micro-granules. Cells 7.5-9 $\mu \mathrm{m}$ in diameter, 3.5-7 $\mu \mathrm{m}$ long. Trichomes aggregates to form a mucilaginous blackish green plant mass.

14. Oscillatoria limnosa Agardh. (Fig. 3) Hirose 1977, P. 102, Pl. 44, Fig. 15; Prescott 1975, P. 489, Pl. 109, Fig. 17.

Trichomes straight, not constricted at the crosswalls which are granular. Apical cell round, Cells 10-12 $\mu \mathrm{m}$ in diameter, 2-4 $\mu \mathrm{m}$ long. Dark blue green in colour.

\section{Oscillatoria anguina (Bory) Gomont (Fig. 6)}

Hirose 1977, P. 102, Pl. 44, Fig. 28.

Trichomes straight for most of their lengths but bent and sometimes twist in the apical regions, slightly tapering towards the apex. Apical cell with capitata. Cells not constricted at the crosswalls, which are granular. Cells $7.5 \mu \mathrm{m}$ in diameter, $2 \mu \mathrm{m}$ long. Dark blue green in colour.

\section{Oscillatoria articulata Gardner (Fig. 5)}

Prescott 1975, P. 486, Pl. 107, Fig. 22.

Trichomes with a thickened outer membrane, not tapering at the apices, Apical cell rounded, not capitates, without a calyptra. Cells $2.5-3.5 \mu \mathrm{m}$ in diameter, 1.2$3.5 \mu \mathrm{m}$ long. Blue green in colour. Not constricted.
17. Oscillatoria princeps Vaucher ex. Gomont. (Fig. 4)

Desikachary 1959, P. 210, Pl. 37, Figs. 1, 10, 11, 13, 14.

Trichomes blue green to dirty green, mostly forming a thallus, mostly straight not constricted at the cross walls, slightly or briefly attenuated at the apices and bent. Cells $13.3 \mu \mathrm{m}$ broad and $2.6 \mu \mathrm{m}$ long, granulated end cell flatly rounded, slightly capitates with slightly thickened membrane.

18. Oscillatoria subbrevis Schmidle (Fig. 22)

Desikachary 1959, P. 207, Pl. 37, Fig. 2; Pl. 40, Fig. 7.

Trichomes single, light blue green, nearly straight, apices not attenuated, septa not granulated, indistinct, cells 5.76-6.2 $\mu \mathrm{m}$ broad and 0.96-1.9 $\mu \mathrm{m}$ long, granulated end cell rounded, calyptras absent.

19. Oscillatoria tenuis Agardh. (Fig. 18)

Hirose 1977, P. 102, Pl. 44, Fig. 25.

Trichomes straight or slightly flexuous at the anterior end, which does not tapper, homogenous sheath frequently present. Apical cell round and not capitate. Trichomes only slightly constricted at the cross walls, which are granular. Cells 5-10 $\mu \mathrm{m}$ in diameter, 2.5-4 $\mu \mathrm{m}$ long. Trichomes aggregates to form a blue green mass.

\section{Genus: Phormidium Kutz.}

20. Phormidium inuatum Kutz. Ex. Gomont. (Fig. 19)

Kützing 1895, P. 251; Gomont 1892, P. 172, Pl 4, Figs. 31-32,

Thallus blue green, membranous, filament sub erect, when dry fragile, sheath thin, becoming diffluent, trichomes blue green, 
P.P. Baruah, B. Kakati and I. Ahmed / Our Nature (2009) 7: 139-145

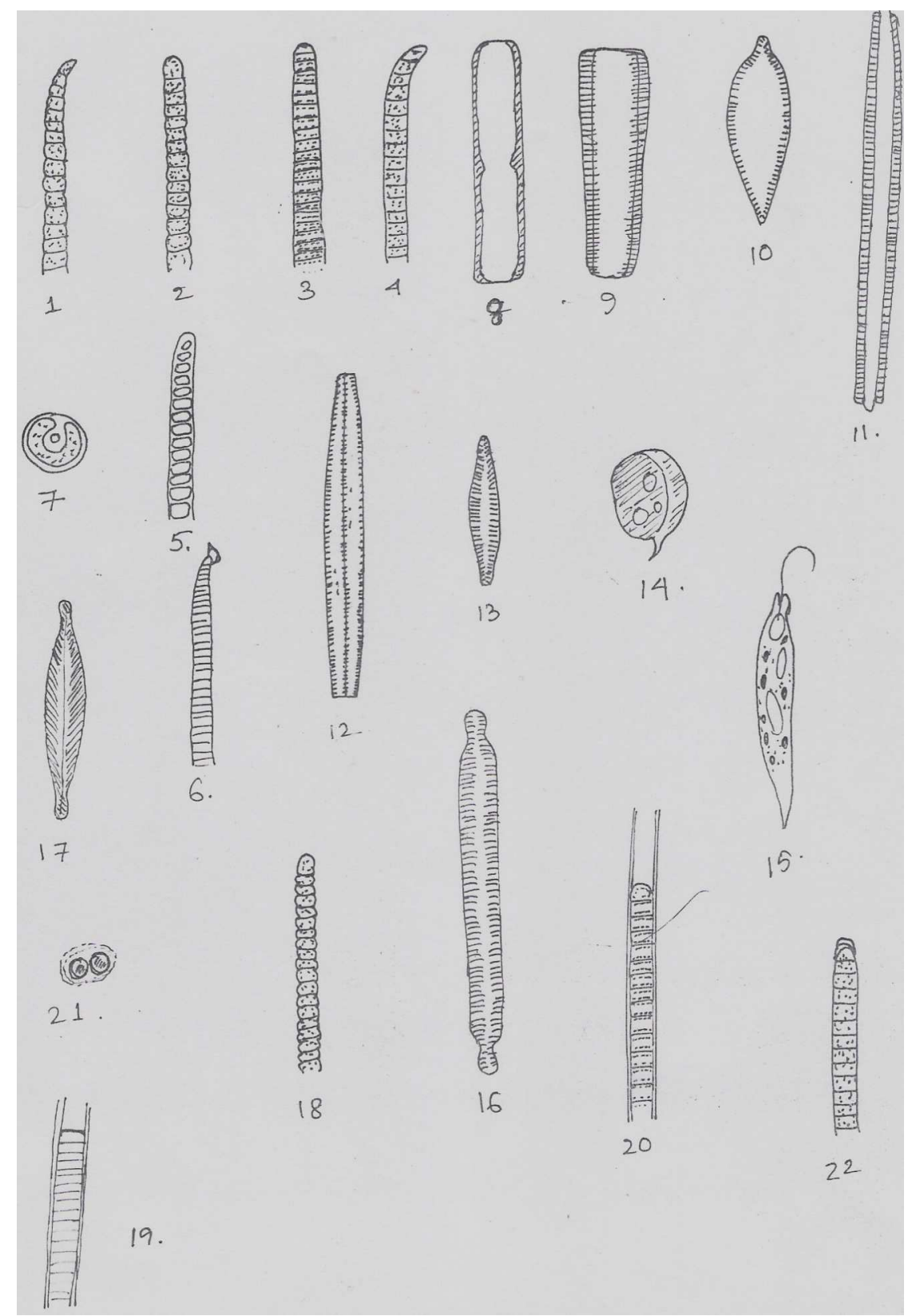

Figures: 1. Oscillatoria formosa Bory 2. O. nigra Vaucher 3. O. limnosa Agardh, 4. O. princeps Vaucher ex. Gomont, 5. O. articulata Gardner 6. O. anguina (Bory) Gomont 7. Chlorella vulgaris Beij. 8. Pinnularia gibba Ehr. var. mesogongyla (Ehr.) Hust. 9. Gomphonema lenceolatum Her. 10. G. parvulum (Kg.) Grun. 11. Synedra ulna (Nitz.) Her. 12. Fragillaria crotonensis var. praelonga Grun. 13. Nevicula cryptocephala Kütz. 14. Phacus acuminatus a. Stokes 15. Euglana acus Her. 16. Fragillaria virescens Ralf. 17. Nevicula rhynchocephala Kütz. 18. Oscillatoria tenuis Agardh 19. Phormidium inuatum Kütz. ex. Gomont 20. Lyngbya birgei Smith 21. Chroococcus montanus Hansging 22. Oscillatoria subbrevis Schmidle 
straight or bent, not constricted at the cross walls, ends straight, briefly attenuated, not capitates, 3-5 $\mu \mathrm{m}$ broad cells nearly quadrate or longer than broad, 4-8 $\mu \mathrm{m}$ long, granulate at the septa, calyptras absent.

\section{Genus: Lyngbya Agardh 1824}

\section{Lyngbya birgei Smith. (Fig. 20)}

Gomont 1892, P. 91-264, Pl. 7; Smith 1950, P. 577, Fig. 492.

Filamentous straight, seldom coiled, free floating, 20-25 $\mu \mathrm{m}$ broad sheath firm, colorless, trichomes not constricted at the cross walls, 18-23 $\mu \mathrm{m}$ broad, ends rounded, not attenuated, not capitates. Cells 2-2.5 $\mu \mathrm{m}$ long, hormogons are 22-25 $\mu \mathrm{m}$ broad, 5-7 celled.

Order : Chroococcales

Family: Chrooccaceae

Genus: Chroococcus Nageli 1849

22. Chroococcus montanus Hansging. (Fig. 21)

Desikachary 1959, P. 108, Pl. 26, Fig. 12

Thallus slimy, gelatinous, brownish or blackish brawn, cells 4.9-6.5 $\mu \mathrm{m}$, seldom $9.9 \mu \mathrm{m}$ diameter, single or $2-4$, seldom more in irregular groups, $19-25 \mu \mathrm{m}$ in diameter, sheath is lamellate.

\section{Results and discussion}

Taxonomic investigations on the algal flora of North Eastern region of India in general and Assam in particular are still very limited and most studies were performed in ponds, Ditches and in rice fields (Parukutty, 1939; Bordoloi, 1974; Devi, 1981; Devi and Boissya, 1981; Talukder, 1997; Choudhury, 2004). In the present study, altogether 22 algal species have been reported to be present in the hydrocarbon polluted drains that have been passing through the Guwahati oil refinery. Cyanophyceae was represented by eleven species in the study sites followed by Bacillariophyceae with eight species. Euglenineae and Chlorophyceae were represented two and one species respectively. Chlorella vulgaris Beij. was the lone genus that belongs to Chlorophyceae. Oscillatoria was found to be the dominant genus with eight species and widely available throughout the study period. All the species have for the first time morpho-taxonomically described from the hydrocarbon contaminated sites of the region and, thus opens up a new area of research in the region. The oil refinery effluent drains therefore, need more attention and require a more extensive exploration and documentation of its algal flora. The establishment of an algal database in those hydrocarbon polluted sited would be an essential contribution to the conservation of hydrocarbon resistant and hydrocarbon tolerant aquatic biodiversity.

\section{Acknowledgements}

All authors are thankful to the Head, Department of Botany, Gauhati University, Guwahati, Assam, India for laboratory facilities

\section{References}

Bordoloi, R.P.M. 1974. Studies on algal flora of Assam. Gauhati University, Guwahati, India. (Ph.D. Thesis)

Choudhury, K. 2004. Taxonomy and ecology of teagarden soil algae of Assam with special reference to pesticide toxicity. Gauhati University, Guwahati, India. (Ph.D. Thesis)

Desikachany, T.V. 1959. Cyanophyta. ICAR Monograph, New Delhi. 686p.

Devi, P. 1981. Taxonomical and Ecological Studies on Algal flora of Darrang District of Assam. Gauhati University, Guwahati, India. (Ph.D. Thesis) 
P.P. Baruah, B. Kakati and I. Ahmed / Our Nature (2009) 7: 139-145

Devi, P. and C.L. Boissya 1981. Addition to algal flora of Assam II. A few Formidium species from the Paddy fields of Assam. Proc. National Academy of Sciences. 4(2): 65-67.

Fritsch, F.E. 1935. The structure and the reproduction of the algae, Vol-I, University Press, Cambridge. $791 \mathrm{p}$.

Fritsch, F.E. 1961. The structure and the reproduction of the algae, Vol-II, University Press, Cambridge. $791 \mathrm{p}$.

Germain, H. 1981. Flore Des Diatomees Diatomophocees. Societe nouvelle Des Editions BOIUBES, PARIS. 441p.

Gomont, M. 1892a. Monographe des Oscillatoriees, $I$. Ann. Sc. Nat. Bot. 7(15): 263-368.

Gomont, M. 1892b. Monographe des Oscillatoriees, II. Ibid. 7(16): 91-264.

Hirose, H., K. Akiyama, K. Ioriya, H. Imahori, S. Kasaki, H. Kumano, Kobayashi, E. Takahashi, K. Tsumura, M. Hirano and T. Yamagishi 1977. Illustration of the Japanese freshwater algae. Uohida Rokakauho, Tokyo, Japan. 933p.

Hustedt, F. 1930. Die Susswasserflora Mitteleuropas. Heft 10. $2^{\text {nd }}$ Edition. Bacillariophyta (Diatomeae). (Ed. A. Pascher) Verlag von Gustav Fischer, Germany. 466p.

Islam, A.K.M.N. and A.K.Y. Haroon 1975.
Limnological studies of the river Buriganga. II. biological aspects. Dhaka University Studies B 23(1): 25-44.

Islam, A.K.M.N. and A.R. Choudhury 1979. Hydrobiological Studies of Dhanmondi Lake, Decca, II phytoplankton. J. Asiatic Soc. Bang. (Sc.) 5(2): 47-57.

Kützing, F.T. 1895. Species Algarum VI (1), Brockhaus, Leipzing. 922p.

Parukutty, P.R. 1939. Collection of Algae from Assam. Proc. Indian Acad. Sci. IX B. 5: 229-235.

Patrick, R. and C.W. Reimer 1966. The diatoms of theUnited States, exclusive of Alaska and Hawaii. Monograph of the Academy of Natural Sciences, Philadelphia, No. 13, Vol. I. 688p.

Prescott, G.W. 1975. Algae of the Western Great Lake area. W.Mc. Brown company publishers, Iowa.

Sarode, P.T. and N.D. Kamat 1984. Freshwater diatoms of Maharastra. Saikripa Publication, Aurangabaa, 338p.

Smith, G.M. 1950. The freshwater Algae of the United States. Mc. Grew Hill book company, Inc. New York. Toronto. 719p.

Talukdar, R. 1997. A taxonomical and ecological survey of blue green algae of Kamrup District, Assam. Gauhati University, Guwahati, India. (Ph.D. Thesis) 